\title{
Distribución pasada y futura del color en edificios históricos de piedra
}

\section{Past and future colouring patterns of historic stone buildings}

\author{
C. M. Grossi ${ }^{(*)}$ y P. Brimblecombe(*)
}

Recepción/Received: 13-VII-07

Aceptación/Accepted: 13-XI-07

Publicado online/Online publishing: 14-I-08

\section{RESUMEN}

La distribución del color en edificios de piedra varía con el tiempo. En el pasado, el ennegrecimiento se debía principalmente a la combustión de carbón. Actualmente, se debe fundamentalmente al depósito de partículas derivadas del diesel. En el futuro, se verá modificado por la acción de la lluvia y el viento. La percepción del público sobre el ennegrecimiento depende de su distribución. Si se resaltan las formas arquitectónicas, será en general aceptable. Los umbrales de aceptación también dependen de la concentración de carbono elemental. Si la concentración es elevada, como en áreas de tráfico intenso, los edificios estarán oscurecidos y probablemente se percibirán como inaceptablemente sucios. A menores concentraciones de carbono elemental $\left(2-3 \mu \mathrm{g} \mathrm{m}^{-3}\right)$, el aspecto de los edificios es en general más aceptable. En el futuro, los cambios de color se verán favorecidos por la diferente actividad biológica, resultante del cambio climático y los diferentes tipos de contaminantes. Un proceso de amarilleamento será probablemente más relevante. Las partículas derivadas del diesel son ricas en compuestos orgánicos que se pueden oxidar a materiales similares a sustancias húmicas (HULIS) de tonos marrones.

Palabras clave: pátina, distribución del ennegrecimiento, contaminación atmosférica, cambio climático, estética.

\section{SUMMARY}

The patterns of colour on stone buildings change with time. Buildings were blackened by coal soot, but now mostly diesel particles and in future, wind-driven rain may alter the patterns and oxidation of surface organics. Colouring patterns that outline or shadow architectural elements are publicly more acceptable than those that cut across them e.g. rain streaking. Thresholds of acceptability for blackening can be related to soot loading. When soot loading of the ambient air is high, e.g. near busy roads, buildings are dark and typically viewed as unacceptable. However at lower concentrations (2-3 $\mathrm{g} \mathrm{g} \mathrm{m}^{-3}$ elemental carbon), building appearance is typically seen as more acceptable. The future offers a potential for variation in building colour, arising through different biological growth under changing climates or the presence of different pollutants. In future urban atmospheres more dominated by organic pollutants a yellowing process may be more important. Diesel soot has many organic compounds that can oxidise to brownish-coloured humic-like (HULIS) materials.

Keywords: patina, blackening patterns, air pollution, climate change, aesthetics.

\footnotetext{
(*) University of East Anglia. Norwich.
} 


\section{INTRODUCCIÓN}

\subsection{Antecedentes históricos}

La decoloración y particularmente el ennegrecimiento de las superficies de piedra han levantado siempre inquietud sobre el aspecto de los edificios. Ya en la época romana Horacio hace referencia a lo ofensivo del ensuciamiento de los templos por el humo atmosférico. A mediados del siglo XVII, expertos en arquitectura, como por ejemplo John Evelyn, mostraban su preocupación sobre el aspecto grotesco de los edificios de Londres cubiertos de hollín (1). Durante la segunda mitad del siglo XX el ennegrecimiento seguía siendo un problema importante (2). Aunque la decoloración de los edificios de zonas urbanas se considera a menudo como negativa, la percepción del ennegrecimiento depende de cada persona y de las condiciones generales del ambiente local (2). El color de edificios históricos puede dar una sensación de antigüedad y su tono representar una especie de pátina (3) imprimiéndole carácter y un aspecto estético beneficioso. En general, el público opina que los edificios antiguos no deben dar el aspecto de estar inmaculadamente limpios o parecer recién estrenados. Este equilibrio es delicado y muy dependiente de la percepción de cada individuo. Una decoloración intensa puede oscurecer detalles arquitectónicos y a menudo la distribución del ennegrecimiento puede resultar en formas visualmente desagradables y sugerir una mala gerencia del edificio.

\subsection{Mecanismos de decoloración}

Tradicionalmente el ennegrecimiento de los edificios en ambientes urbanos era debido al depósito del hollín derivado de la combustión de carbón. Actualmente se debe principalmente al depósito de partículas derivadas del diesel (4). Con el tiempo la lluvia dirigida por el viento (wind-driven rain) altera la distribución del ensuciamiento (5). La actividad biológica, probablemente acentuada por un aumento del depósito de nitratos y contaminantes orgánicos, puede también contribuir significativamente al ennegrecimiento de la piedra (6).

La investigación sobre cambios en la distribución del ennegrecimiento en edificios de Oxford parece indicar que la colonización biológica conduce a una distribución no uniforme del ennegrecimiento (7). Esta respuesta biológica a los cambios en la contaminación y el clima muestra una complejidad específica de cada lugar de estudio (8). De este modo, se encontró que el ennegrecimiento de ciertos monumentos iraníes era principalmente debido a la acción de cianobacterias (9). También se atribuyó un origen biológico a pátinas rojizo-anaranjadas de monumentos mediterráneos, con los óxidos de hierro y la materia orgánica actuando como colorantes de la pátina $(10,11)$. Por otra parte, en este área, y desde la antigüe-

\section{INTRODUCTION}

\subsection{Historical origins}

The discolouration and particularly the blackening of stone surfaces has always raised disquiet about the appearance of buildings. In Roman times Horace was much concerned with the offence created by smoke begrimed temples. By the mid 1600s, those concerned with architectural form, such as the diarist John Evelyn, were particularly worried about the ugliness of London's sootencrusted buildings (1). During the second half of the 20th century blackening remained an important issue (2). Although discolouration of buildings exposed to urban atmospheres are often seen as negative, the perception of blackening depends on the individual and general conditions of the local environment (2). It may be that the colour of historic buildings gives a sense of their age or is an important function of their location. The tone they display can represent a kind of patina (3) that is a part of their character and thus aesthetically beneficial. Often those who visit old buildings believe that they should not appear brand new or scraped clean. This balance is a delicate one and very dependent on perceptions as heavy discolouration can obscure architecture and often blackening takes on patterns that have long been regarded as offensive or suggest poor management.

\subsection{Mechanisms of discolouration}

Buildings were blackened by coal soot in past urban environments, but are now discoloured through the deposition of diesel particles (4). Over time wind-driven rain alters the soiling patterns (5). Biological activity, perhaps supported by an ongoing increase in nitrate deposition and organic pollution, may also contribute significantly to stone blackening (6).

Research on changing patterns of soiling in Oxford suggested that biological colonisation leads to non-uniform soiling patterns (7). These biological responses to changes in pollution and climate show a clear site-specific complexity (8). Black deposits on surfaces of some Iranian monuments were found to be mainly microbiotic crusts produced by cyanobacterial growth (9). Some orange reddish patinas on Mediterranean monuments were attributed a biologically induced formation with organic matter and iron oxides playing a role as colouring patina $(10,11)$. Moreover, in this area, coloured artificial patinas and surface treatments were applied since ancient times to improve the aesthetic and durability of 
dad se aplicaron pátinas artificiales de diferente color y tratamientos superficiales con el fin de mejorar el aspecto estético y la durabilidad de la superficie de los materiales (12). Además la oxidación de los compuestos orgánicos puede dar lugar a tonos más cálidos (13). Estos tonos más cálidos se perciben a menudo en las superficies de piedra cuando se eliminan las costras negras (14-16). En futuras atmósferas urbanas con un dominio de contaminante orgánicos este proceso de amarilleamiento puede llegar a ser más importante, ya que las partículas diesel presentan muchos compuestos orgánicos que se pueden oxidar a HULIS (humic-like materials) que presentan unos colores pardos.

Andrews (17) estudió la estética del ensuciamiento en edificios y concluyó que el ennegrecimiento de las superficies puede considerarse aceptable si no es muy elevado y está uniformemente distribuido. La distribución del ennegrecimiento también puede ser aceptable si crea un efecto de sombra que acentúe las formas arquitectónicas. En este sentido, hemos recogido algunos comentarios relevantes sobre el aspecto de la fachada de la histórica Casa la Rúa (Oviedo, Asturias-España). Esta fachada está construida fundamentalmente por una caliza amarillenta y exhibe áreas claras y oscuras, marcadas por surcos verticales negros de depósitos de combustión y verdes de crecimiento biológico. Los comentarios de visitantes incluyen expresiones como "está más clara que antes, yo la conocí cuando era totalmente negra" y sobre el color "deber ser más claro o más oscuro, pero no así". Esta declaración sugiere que la distribución puede llegar a ser más importante que el color en sí mismo.

\subsection{Tendencia de los cambios de color}

La tendencia del cambio de color y del ennegrecimiento se puede determinar experimentalmente. Sin embargo, los modelos usados para analizar los datos, sobrestiman a veces el oscurecimiento porque se asume con frecuencia que las fachadas llegan a ennegrecerse totalmente. Éste no es el caso, ya que incluso después de períodos largos de exposición, la reflectancia puede presentar valores asintóticos incluso de un $45 \%$. Por tanto, el proceso de ennegrecimiento se ajusta más a un modelo exponencial que tienda a un determinado valor asintótico diferente de cero. Sin embargo, los datos experimentales generalmente cubren solamente períodos de exposición cortos, por lo que el establecimiento del modelo puede ser difícil de llevar a cabo.

Otra complicación adicional es que en muchos lugares, el depósito de contaminantes de color oscuro ha disminuido sustancialmente debido a la reducción actual de las emisiones. En tales situaciones, las fachadas pueden estar sometidas a procesos de auto-limpieza por la acción de la lluvia y del viento (5). Como ejemplos podemos the surfaces (12). In addition the oxidation of surface organics can cause warmer tones (13). These warmer tones are often found on stone surfaces when black crusts are removed (14-16). In future urban atmospheres more dominated by organic pollutants this yellowing process may become more important, particularly as diesel soot has many organic compounds that can oxidise to brownish-coloured humic-like materials.

Andrews (17) studied the aesthetics of soiling patterns on buildings, considering the blackening of building surfaces to be acceptable if it remains as a fairly low level and is uniform in distribution. Furthermore, blackening patterns can be acceptable if they create shadowing effects that emphasise the architectural form. Some visitors to the historic Casa de la Rúa (Oviedo, Northern Spain) gave relevant comments on appearance of the façade. This house is built in a yellowish limestone and exhibits light and dark areas with heavy black and green vertical streaking. Visitors remarked of the appearance "it's lighter than before, I knew it when it was completely black" and about the colour they said it should be "lighter or darker, but not like this". This statement suggests that patterns can easily become more important than the colour itself.

\subsection{Rate of change}

The rate of blackening and colour change can be readily determined from a series of measurements. However, models used to analyse the data, sometimes overestimate the predicted darkening because they frequently assumed that facades become completely black. This is not the case as the asymptotic reflectance is often as high as 45\% even after long time periods. Thus the blackening process is best modelled with an exponential fit that tends to some non-zero asymptotic value. Nevertheless, this can be difficult to do with records that cover only short time periods.

A further complication arises in many locations, where the deposition of dark coloured pollutants has now substantially decreased as emissions have declined. In such situations, façades may self-clean through the influence of rain and wind (5). The loss of black deposits has become apparent at the Cathedral of St. John the Baptist in 
citar la catedral de San Juan Bautista en Norwich (UK), donde la disminución de depósitos negros es actualmente evidente o la fachada principal de la catedral de Oviedo, que mantiene un sus tonos claros incluso después de siete años de la limpieza del año 2000 . Todo esto contrasta con la primera mitad del siglo $\mathrm{XX}$, donde los edificios de zonas urbanas se ennegrecían incluso antes de ser acabados $(2,5)$. La reducción de la capacidad de ennegrecimiento facilita la visualización de coloraciones más tenues. La Torre de Londres es un ejemplo de un conjunto de edificios donde actualmente se pueden observar los tonos más cálidos.

\subsection{Percepción}

La opinión pública sobre la decoloración de las superficies es importante de cara a la gerencia de los edificios históricos. La necesidad de obras de limpieza se puede relacionar con la percepción de los visitantes sobre la luminosidad de las fachadas de piedra (18). Los patrones o distribución del ennegrecimiento también influyen en las reacciones de la población. En trabajos previos, hemos examinado respuestas a distribuciones de ennegrecimiento simuladas por ordenador. Nuestra investigación ha corroborado resultados anteriores e indica que mientras algunas distribuciones se consideran aceptables, otras provocan serias reacciones adversas, como por ejemplo los surcos verticales de ennegrecimiento. También hemos observado, en general, reacciones adversas a las formas de ennegrecimiento con una dimensión fractal mayor que la unidad. Esto puede ser debido a que estas distribuciones están en conflicto con las líneas arquitectónicas del edificio (19).

La respuesta pública a la cantidad de decoloración de edificios europeos se ha examinado recientemente usando cuestionarios in-situ $(18,20)$. En ellos, hemos pedido a los visitantes que juzgaran el tono de un edificio mediante una comparación con una escala de grises. Las personas que participaron en la encuesta encontraron relativamente poca dificultad en la comparación, de manera que nos permitió evaluar la luminosidad o claridad percibida del edificio. Como cabía esperar, cuanto más clara se percibe la fachada, más bajo es el deseo de obras de limpieza. La relación entre las percepciones de suciedad y luminosidad de las fachadas nos permitió estimar umbrales de niveles aceptables de ennegrecimiento (18). Estos umbrales estéticos se pudieron relacionar con la concentración de carbono elemental (CE) en la atmósfera. Los umbrales muestran como en zonas de alta concentración de CE adyacentes a tráfico intenso, los edificios pueden llegan a percibirse inaceptablemente oscuros. Cuando las concentraciones son más bajas, en el rango de $2-3 \mu \mathrm{g} \mathrm{m}^{-3} \mathrm{de} \mathrm{CE}_{\text {, }}$ el aspecto de los edificios es más aceptable. Al no disponer de valores de CE para todos los lugares de estudio, éstos se estimaron mediante un análisis cluster de las
Norwich. Additionally, the main façade of the Cathedral of Oviedo was cleaned during 2000, but seven years later it has managed to keep its unsoiled appearance. This contrasts with the first half of the 20th century where new urban buildings become black often before they were finished $(2,5)$. The lower potential for blackening has made subtle colorations more easily observed. The Tower of London is an example of an ensemble of buildings where warmer tones are now apparent.

\subsection{Perceptions}

The public reaction to the discoloured surfaces is relevant to the management of historic buildings. Pressure for cleaning can be related to visitor perceptions of the lightness of the stone facades (18). The patterns of blackening are also part of the public response. We have examined responses to computer simulated blackening patterns. Our research corroborates earlier findings that while some patterns are considered acceptable, others provoke strong negative reactions. For example, pronounced vertical streaking or lumpiness was often disliked. We also noted that patterns with a fractal dimension greater than unity were objectionable. This may have been because the patterns were in conflict with the architectural lines of the building (19).

Public response to the amount of discolouration of European buildings has recently been examined using in situ questionnaires $(18,20)$. We asked visitors to judge the tone of a building by comparison with a grey scale. They had relatively little difficulty in doing this, so we were easily able to establish the perceived lightness of building. The lighter the perceptions of the buildings, quite naturally, the lower the pressure for cleaning from the respondents. The relationship between responses that a building was dirty and the perceived lightness allowed us to estimate a threshold for acceptable levels of blackening (18). Such aesthetic thresholds could be related to soot loading in the atmosphere, which suggested that at high soot concentrations near busy roads, buildings were viewed as unacceptably dark. When concentrations are lower, in the range 2-3 $\mu \mathrm{g} \mathrm{m}^{-3}$ (as elemental carbon EC), the appearance of buildings becomes more acceptable. The values of EC are often not known at specific sites, but they were estimated through a cluster analysis of EC concentrations at a range of exposure sites. In the past, it is likely that historic buildings were exposed to much higher concentrations of $E C$, so in many 
concentraciones de CE en una serie de zonas de diferente exposición. En el pasado, es probable que los edificios históricos estuvieran expuestos a concentraciones de CE mucho más elevadas. La mejoría general en la calidad del aire posiblemente conlleve una disminución del ennegrecimiento de fachadas (21).

\subsection{Objetivos}

El objetivo de este trabajo es poner de manifiesto los probables cambios en las tendencias actuales del ennegrecimiento de edificios históricos en zonas urbanas. La reducción de la contaminación puede conllevar una auto-limpieza de las fachadas de edificios históricos por la lluvia. Como consecuencia, los procesos de ennegrecimiento dan lugar a fachadas de tonalidades más claras, es decir el valor asintótico de la reflectancia es más alto que en el pasado. Puede también ocurrir que cambios tenues en el color, resultado de procesos de oxidación y de actividad biológica, sean más obvios en estas superficies más limpias. Finalmente, apuntamos a la necesidad de cambiar los métodos de gerencia y mantenimiento de edificios históricos adoptados en el pasado. Así, la noción de operaciones de limpieza después de períodos fijos de tiempo es difícil de justificar, dada la complejidad de los procesos en atmósferas urbanas y clima en constante cambio.

En este artículo se presentan resultados de investigaciones recientes sobre procesos y tendencias en los cambios del color de los edificios de piedra, principalmente ennegrecimiento y amarilleamiento. Hemos usado la catedral de San Juan Bautista en Norwich (UK) como ejemplo ilustrativo de los cambios en curso, examinando su apariencia pasada y su probable aspecto futuro.

\section{OBSERVACIONES, RESULTADOS Y DISCU- SIÓN}

\subsection{Medidas experimentales del cambio de color}

Las variaciones del color se han determinado con un colorímetro y se han expresado usando los sistemas de color CIEL*a*b * y CIEL*C*h, que dan una buena representación de la percepción humana del color. En estos sistemas $L^{*}$ es la luminosidad, que varía de negro al blanco, mientras que a*(rojo-verde) y b* (azul-amarillo) son las coordenadas cromáticas. El valor $\mathrm{C}^{*}$ es el croma, saturación o pureza del color, y h es el ángulo de la tonalidad en la rueda del color. Las medidas experimentales en piedras expuestas a atmósferas urbanas muestran como se producen cambios importantes en $L^{*}$ con el tiempo, y variaciones menores pero significativas en la coordenada $b^{*}$. Estos cambios en $b *$ representan un proceso de amarilleamiento que puede ser más rápido que el ennegrecimiento (13). locations improved air quality means blackening should decline (21).

\subsection{Objectives}

In this paper we would like to stress changes now apparent in modern cities. The reduced pollution concentrations can mean that façades of historic buildings are cleaned as rain washes the surfaces and thus asymptotic blackening will be reached at lighter shades. It may also be that subtle changes in colour, that result from the oxidation and biological activity, will be more obvious on these cleaner surfaces. We also examine how simple management approaches adopted in the past may have to change. Thus suggestions that buildings be re-cleaned after fixed periods of time is now much harder to justify, given the complexity of processes in an ever changing urban atmosphere and climate.

Here, we present recent research on processes and the rates for changes in colour patterns of stone buildings, mainly blackening and yellowing. We consider the Cathedral of St. John the Baptist in Norwich as illustrative of changes underway and examine its past condition and likely future appearance.

\section{OBSERVATIONS, RESULTS AND DISCUS- SION}

\subsection{Measurement of change}

Colour variations were determined with a colorimeter and reported using the CIEL*a*b* and CIEL*C*h systems, which give a good representation of the human sensibility to colour. In these systems $L^{*}$ is lightness, which ranges from black to white, while $a^{*}$ (red-green) and $b^{*}$ (blue-yellow) are the chromatic co-ordinates. The value $C^{*}$ is the chroma, saturation or colour purity, and $h$ is the hue angle in the colour wheel. Experimental measurements on outdoor stone at numerous urban sites show there are changes in $L^{*}$ over time and smaller, but significant changes in the colour co-ordinate $b^{*}$. These changes in $b^{*}$ represent a yellowing process that can be faster than the blackening (13). 
El descenso de $L^{*}$ (ennegrecimiento) y el aumento en $b^{*}$ (amarilleamiento) siguen expresiones exponenciales como [1]:

$$
L *_{t}=L *_{o}-\left(L *_{o}-L_{\infty}\right) \cdot[1-\exp (-k t)]
$$

$\mathrm{L}_{\mathrm{t}}$ o el $\mathrm{b}{ }_{\mathrm{t}}$ es $\mathrm{L} *_{\mathrm{o}} \mathrm{b} *$ en el tiempo $\mathrm{t} ; \mathrm{L}^{*}{ }_{0} \circ \mathrm{b}^{*}{ }_{0}$ es el color inicial de la piedra y $\left(\mathrm{L} *_{0}-\mathrm{L} *_{\infty}\right)$ o $\left(\mathrm{b} *_{0}-\mathrm{b} *_{\infty}\right)$ es el cambio total. El valor $\mathrm{k}$ es el coeficiente del proceso $\mathrm{y}$ depende probablemente de procesos de depósito y lavado o redistribución. Su recíproco $1 / k$ se puede considerar como una especie de folding time o más familiarmente $\ln (2) / k$, que sería la vida media del proceso (22).

La modelización llevada a cabo dentro del proyecto europeo CULSTRAT (23) adoptó un ajuste asintótico a reflectancia cero. Sin embargo, este modelo puede sobrestimar el ennegrecimiento a largo plazo. En el proyecto, sin embargo, se mencionan algunas limitaciones del método, tales como no considerar los procesos de eliminación de depósitos y asumir que las capas de depósitos tienen una reflectancia cero.

\subsection{Tendencias de ennegrecimiento}

El ennegrecimiento de las piedras de edificación sigue el modelo exponencial con una asíntota diferente de cero, expresado en la ecuación [1]. Este modelo es físicamente realista y parece explicar mejor que otros modelos el proceso de ennegrecimiento para registros de medidas largos (22). Los parámetros de la ecuación exponencial son difíciles de resolver para registros cortos (es decir registros de medidas donde no hay un cambio sustancial en la reflectancia, quizás menos de una tercera parte del máximo cambio posible), porque la línea es tan recta que las funciones no lineales son difíciles de ajustar (Figura 1). Esta linealidad tiende a desaparecer y la relación se
Decreases in $L^{*}$ (blackening) and increases in $b^{*}$ (yellowing) follow exponential expressions such as [1]:

$b *_{t}=b *_{o}+\left(b *_{o}-b_{\infty}\right) \cdot[1-\exp (-k t)]$

$L^{*}{ }_{t}$ or $b^{*}{ }_{t}$ are $L^{*}$ or $b^{*}$ at time $t ; L^{*}{ }_{0}$ or $b^{*}{ }_{0}$ the initial colour of the stone and $\left(L^{*}{ }_{0}-L_{\infty}{ }_{\infty}\right)$ or $\left(b^{*}{ }_{0}-b^{*}{ }_{\infty}\right)$ the total change. The value $k$ is the rate of the process and probably depends on deposition and removal or redistribution processes. The reciprocal $1 / k$ might be regarded as a kind of folding time or more familiarly $\ln (2) / k$, which would be the half life for the process (22).

Modelling carried out within the European project CULSTRAT (23) adopted a model that is asymptotic to zero. However, this may overestimate long-term blackening and they point out some limitations of the method, such as the exclusion of removal processes and the assumption that the deposited layer has a zero reflectance (i.e. at the asymptote).

\subsection{Blackening trends}

The blackening of building stones follows the bounded exponential form expressed in equation [1], which is physically realistic and seems to explain better than other models the blackening process for long records (22). The exponential parameters are difficult to resolve from short records (i.e. records where there is not a substantial change in the reflectance, perhaps less than a third of the maximum possible change), because the line is so straight that non-linear functions are difficult to fit (Figure 1). This linearity tends to vanish and the rela-

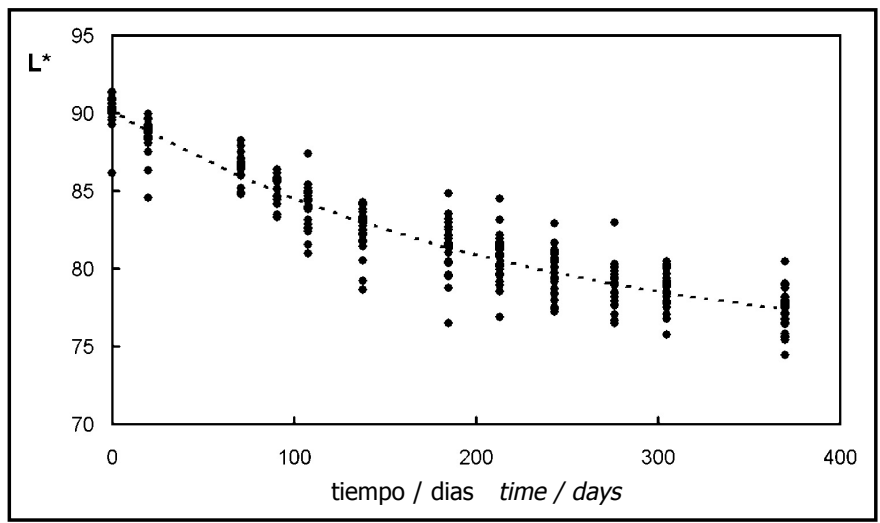

Figura 1. Variación de la luminosidad ( $\left.L^{*}\right)$ en probetas de $5 \times 5 \times 1 \mathrm{~cm}$ de una caliza porosa blanca (Hontoria). Las probetas se expusieron horizontalmente en áreas protegidas de la lluvia en Burgos (más detalles en Grossi et al, 24). Hemos estimado concentraciones de CE típicas de un background urbano $\left(\approx 2-3 \mu \mathrm{g} \mathrm{m}^{-3}\right)$.

Figure 1. The variation of lightness $\left(L^{*}\right)$ for $5 \times 5 \times 1 \mathrm{~cm}$ specimens of a white porous limestone (Hontoria), horizontally exposed in rain-sheltered positions in the city of Burgos (details in Grossi et al, 24). We assumed an EC concentration typical of an urban background $\left(\approx 2-3 \mu g \mathrm{~m}^{-3}\right)$. 
vuelve exponencial cuando se dispone de un registro largo de medidas (varios folding times).

En materiales poco porosos esta relación exponencial puede no explicar la decoloración inicial. Lombardo et al (25) e Ionescu et al (26) usaron un modelo sigmoidal (ecuación de Hill) para explicar el ensuciamiento del vidrio. En este caso, el coeficiente de ensuciamiento aumentaba progresivamente al principio, para más adelante disminuir hasta el valor de saturación. Lombardo et al (25) mencionan que el vidrio es un material no poroso, homogéneo y liso, muy diferente de materiales porosos más rugosos donde el depósito de partículas puede verse favorecido en las etapas iniciales. Los materiales poco porosos, tales como piedra pulida y vidrio son más resistentes a la adhesión de partículas oscuras, lo que se traduce en una inducción más lenta al proceso de ennegrecimiento. La Figura 2 muestra un oscurecimiento inicial lento para el mármol de Macael (un material no poroso) comparado con piedras más porosas: Hontoria, Laspra y Piedramuelle. tionship becomes exponential as measurements become available over many folding times.

With hard materials this exponential relationship may not explain the initial discolouration. Lombardo et al (25) and Ionescu et al (26) fitted a variable slope sigmoid model (Hill equation) for the soiling of silica-soda-lime float glass. Here the rate of soiling increased progressively at the beginning, but later the soiling rate decreased until saturation. Lombardo et al (25) mention that glass is a non-porous, homogeneous and smooth material, so different to rougher porous materials where the deposition of soot and other particulate can be favoured at the initial stages. Low porosity materials, such as smooth stone and glass are more resistant to the dark particle adhesion so require a slower induction period for blackening. Figure 2 shows the slow initial darkening for Macael (a non-porous marble) compared with the more porous stones: Hontoria, Laspra and Piedramuelle.

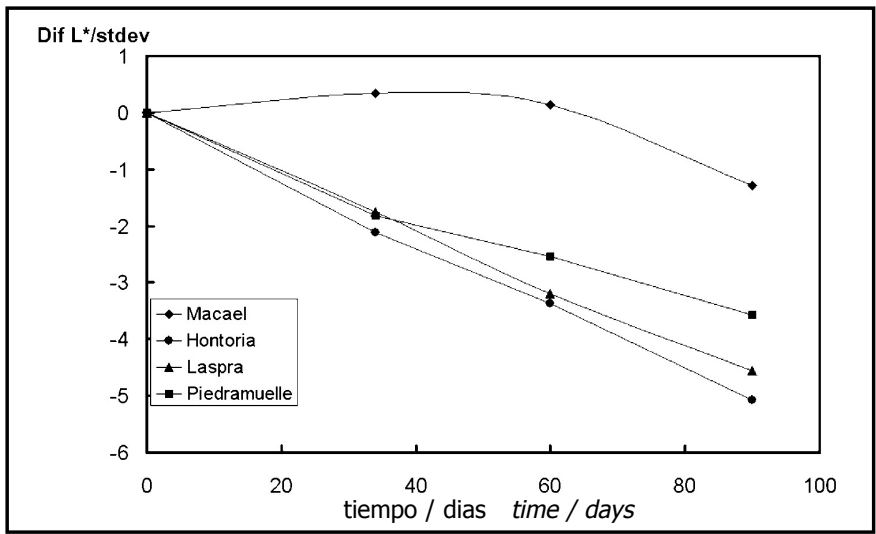

Figura 2. Variación de $L^{*}$ en probetas de $5 \times 5 \times 1 \mathrm{~cm}$ de rocas carbonatadas de color claro (Hontoria, Laspra Piedramuelle y Macael). Las probetas se expusieron horizontalmente en áreas protegidas de la lluvia en Oviedo (más detalles en Grossi et al, 24 y Esbert et al, 27). Hemos estimado concentraciones de CE típicas de un background urbano $\left(\approx 2-3 \mu \mathrm{g} \mathrm{m}^{-3}\right)$. Las escalas de los ejes de ordenadas de las Figuras 1 y 2 son diferentes para mostrar los cambios de luminosidad con más claridad.

Figure 2. The variation of $L^{*}$ in $5 \times 5 \times 1 \mathrm{~cm}$ specimens of light carbonate stone (Hontoria, Laspra, Piedramuelle and Macael) exposed horizontal in rain-sheltered positions at an urban background site in the city of Oviedo (details in Grossi et al, 24 and Esbert et al, 27). We assumed an EC concentration typical of an urban background $(\approx 2-3 \mu g$ $\left.m^{-3}\right)$. The $y$-axis is different to that in Figures 1 and 2 to show the changes clearly.

El valor asintótico del ennegrecimiento depende de los procesos de depósito y de eliminación. Éstos van a depender de la concentración atmosférica de carbono elemental (CE). Dentro del proyecto CARAMEL (http://ec. europa.eu/research/environment/newsanddoc/article _2387_en.htm) hemos recopilado numerosos datos de ennegrecimiento publicados sobre piedras de color claro y los hemos relacionado con el CE atmosférico. El análisis de los datos sugiere una luminosidad asintótica $\left(L_{\infty}^{*}\right)$ que varía desde 75-80\% en zonas remotas (CE $<1 \mu \mathrm{g} \mathrm{m}$ -
The asymptotic blackening value depends on both the deposition and removal processes. These are dependent on atmospheric concentrations of elemental carbon (EC). Within the project CARAMEL (http://ec.europa.eu/research/environment/newsanddoc/article_2387_en.htm) we reviewed extensively published blackening data for lightcoloured stones and related them to atmospheric EC. The analysis of the data hinted that asymptotic lightness $\left(L_{\infty}{ }^{*}\right)$ varied from $75-80 \%$ in remote areas $(E C<1 \mu \mathrm{g} \mathrm{m}$ 3), $60-70 \%$ at urban background sites ( $\left.E C \approx 2-3 \mu \mathrm{g} \mathrm{m}^{-3}\right)$, 
3), 60-70\% en zonas de background urbano, hasta 30$40 \%$ en zonas de intenso tráfico y túneles de carretera (CE > $10 \mu \mathrm{g} \mathrm{m}^{-3}$ ).

También hemos relacionado el ennegrecimiento con la concentración superficial de CE en edificios. Nuestra investigación en la Torre de Londres (28) muestra como la luminosidad $\left(\mathrm{L}^{*}\right)$ de costras negras, medida con un colorímetro, desciende rápidamente a concentraciones bajas de $\mathrm{CE}$, y alcanza exponencialmente un valor límite a altas concentraciones (Figura 3). La figura también sugiere un valor mínimo de la luminosidad $\mathrm{L} *$ alrededor de 35 cuando la concentración superficial de CE en la costra es de alrededor de $10 \mathrm{~g} \mathrm{~m}^{-2}$ o superior. Así una vez que se alcanza una concentración superficial de $10 \mathrm{~g} \mathrm{~m}^{-2}$, es poco probable que los edificios se oscurezcan mucho más. to $30-40 \%$ in highly trafficked areas and road tunnels (EC $>10 \mu \mathrm{g} \mathrm{m}^{-3}$ ).

The blackening is also related to the surface concentration of EC on buildings. Our research at the Tower of London (28) shows that the lightness $\left(L^{*}\right)$ of black crusts measured colorimetrically falls rapidly with EC at low concentrations, and exponentially reaches a limiting value at high concentrations (Figure 3). The figure also suggests a minimum value of lightness $L^{*}$ around 35 where the EC area concentration in the crust is around $10 \mathrm{~g} \mathrm{~m}^{-2}$ and above. Thus once a surface concentration of $10 \mathrm{~g} \mathrm{~m}^{-2}$ is achieved, buildings will be unlikely to become much darker.

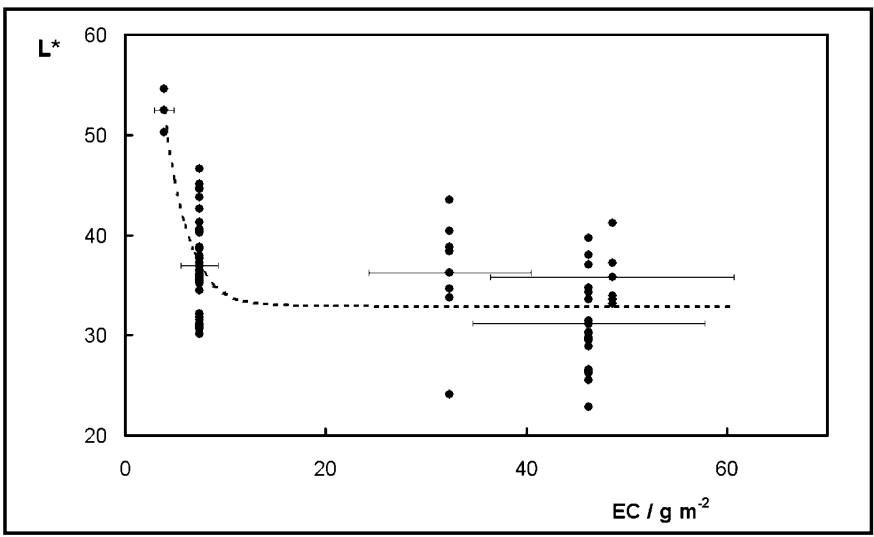

Figura 3. Medidas de luminosidad ( $\left.L^{*}\right)$ en función de la concentración superficial de carbono elemental en costras de la Torre de Londres (más detalles en Bonazza et al, 28).

Figure 3. Measured lightness $\left(L^{*}\right)$ as a function of the area concentrations of elemental carbon in crusts from the Tower of London (see also Bonazza et al, 28).

\subsection{Amarilleamiento}

En las secciones previas, hemos mencionado los tonos cada vez más cálidos de los edificios. Sin embargo, un proceso de amarilleamiento puede medirse con un colorímetro incluso durante los estadios iniciales del depósito de contaminantes (Figura 4). Este amarilleamiento suele ser más rápido que el ennegrecimiento, lo que indica que no son procesos idénticos. El amarilleamiento puede producirse por aumento de la rugosidad superficial, sulfatación, oxidación del hierro en trazas en la piedra, cambios mineralógicos o polimerización de los compuestos orgánicos (13). Este croma puede llegar a ser visible en ambientes urbanos actuales si los depósitos oscuros son eliminados de la superficie de los edificios.

Los depósitos actuales, ricos en materia orgánica, representan un potencial para la actividad biológica y la oxidación a largo plazo. Esto puede dar lugar a diferentes colo-

\subsection{Yellowing}

We have mentioned already the increasingly warm tones found on buildings. However, even during initial deposition of pollutants on a building a yellowing process can be measured with a colorimeter (Figure 4). This process can be faster than the rate of blackening, so it is not an identical process. It could arise from increases in surface roughness, sulfation, oxidation of trace iron in the stone, mineralogical changes, or polymerization of organic compounds (13). If dark particles are later lost from the surface in contemporary urban environments this chroma may be revealed.

In the long term contemporary deposits rich in organic materials offer the potential for biological activity and oxidation. This can produce different colours and patterns, 


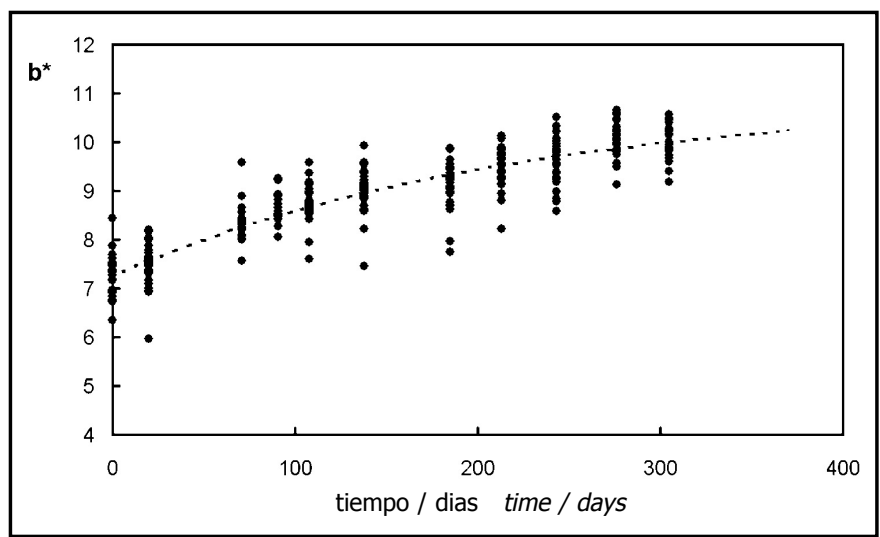

Figura 4. Variación de la coordenada cromática b* en probetas de $5 \times 5 \times 1 \mathrm{~cm}$ de una caliza porosa blanca (Hontoria). Las probetas se expusieron horizontalmente en áreas protegidas de la lluvia en Burgos (datos de Esbert et al, 27).

Figure 4. Variation of the colour coordinate $b^{*}$ for $5 \times 5 \times 1 \mathrm{~cm}$ specimens of a white porous limestone (Hontoria), horizontally exposed in rain-sheltered positions in the city of Burgos (data from Esbert et al, 27).

res y distribuciones, ya que estos depósitos ricos en compuestos orgánicos adquirieren tonalidades pardo-amarillentas. Actualmente se observan valores altos en la relación carbono orgánico / carbono elemental (CO/CE) (29). Por ejemplo, en Florencia este cociente varía entre 1,5 y 2,2, mientras que costras más antiguas muestran cocientes de CO/CE más bajos, como los de la catedral de Milán que oscilan entre 0,1 y 0,7 (30). De manera similar a los suelos, los compuestos de carbono orgánico pueden transformarse lentamente en compuestos similares a sustancias húmicas, HULIS -humic-llike materiales- (31), que presentan tonalidades amarillas o marrones en lugar de negras.

Los cambios del color en las fachadas de los edificios son cada vez más visibles en lugares como la Torre de Londres (13). Aquí hemos encontramos que las costras más modernas presentan cocientes más altos de carbono with the organic rich deposits becoming brownish-yellow. High organic carbon/elemental carbon ratios (OC/EC) are now observed (29). For instance, in Florence it varies between 1.5 and 2.2, while in older crusts the OC/EC ratio is smaller, such as those of the cathedral of Milan varying from 0.1 to 0.7 (30). In a similar manner to soils, organic carbon compounds can be slowly converted to humic like substances, HULIS (31), which are typically yellow or brown rather than black.

Colour changes on building surfaces are increasingly noticed at sites such as the Tower of London (13). Here we found that more modern crusts have higher organic-carbon/sulfur $\left(\mathrm{OC}_{\mathrm{SO}}\right)$ ratios (28). Figure 5 shows measu-

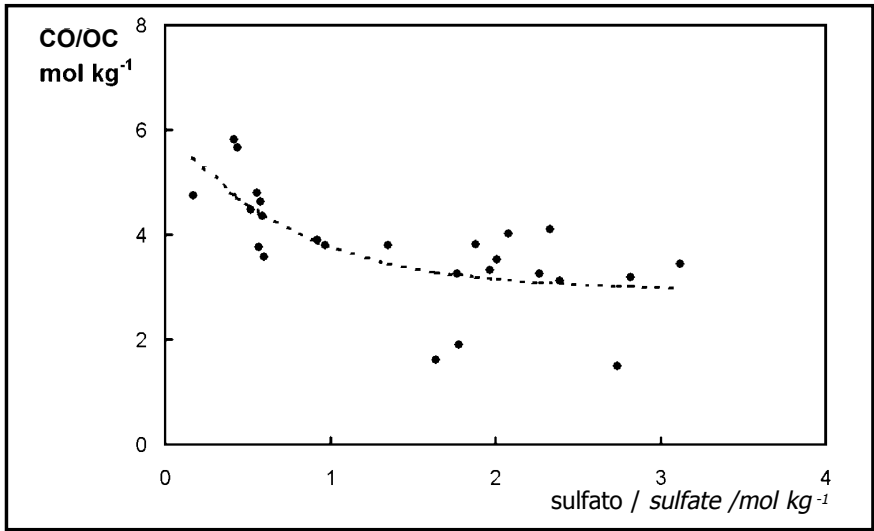

Figura 5. Concentraciones de carbono orgánico (CO) frente a concentaciones de sulfato en costras de varios moumentos europeos (datos de Bonazza et al, 30).

Figure 5. Organic carbon (OC) versus sulfate concentrations from a range of crusts of several European monuments (data from Bonazza et al, 30). 
orgánico/sulfato $\left(\mathrm{CO} / \mathrm{SO}_{4}\right)$ (28). La Figura 5 muestra medidas en una serie de costras de diferentes monumentos europeos e ilustra como las costras más antiguas, con concentraciones altas de sulfato, presentan concentraciones más bajas de carbono orgánico (CO). Esto es debido al cambio del uso de carbón con alto contenido en azufre por combustibles líquidos con contenidos más bajos de azufre, lo que resulta en una carga más alta de carbono orgánico (CO). En décadas recientes las concentraciones más bajas de dióxido de azufre y el depósito en aumento de compuestos orgánicos y de nitrógeno ha favorecido la actividad biológica en los edificios, lo que puede inducir la formación de pátinas de diferentes colores (11).

Aunque el color de los edificios históricos es probablemente percibido por los visitantes, éstos actualmente son más sensibles a los cambios en luminosidad que a la tonalidad o al croma. Esto es comprensible ya que cambios en luminosidad son mucho mayores que los cambios en croma. Así, en nuestros cuestionarios sobre estética del ensuciamiento, las personas encuestadas al describir el color de los edificios de piedra clara, utilizaron palabras tales como crema o gris y no términos que sugirieran colores saturados o intensos. Al comparar el color global del edificio con una escala de color Munsell, los visitantes rements from a range of crusts and illustrates that the older crusts with high sulfate concentrations have lower concentrations of organic material. This comes about through the shift from high sulfur coal to liquid fuels with lower sulfur content, but yielding an increased the organic carbon $(O C)$ load. In recent decades lower sulfur dioxide concentrations and increasing deposition of nitrogen and organic compounds have encouraged biological activity on buildings, which can induce the formation of coloured patinas (11).

Colours are likely to be noticed by visitors, but at present they are more sensitive to changes in lightness than in hue or chroma. This is understandable given the large changes in lightness compared to subtle shifts in chroma. Thus when visitors were asked to describe the colour of historic buildings they chose words such as cream or grey to describe light coloured stones; not terms that suggested saturated or bright colours. When comparing the overall building with a Munsell chart they were tended to choose from tablets of colour that reflected changes in darkness or lightness rather than significant shifts chro-

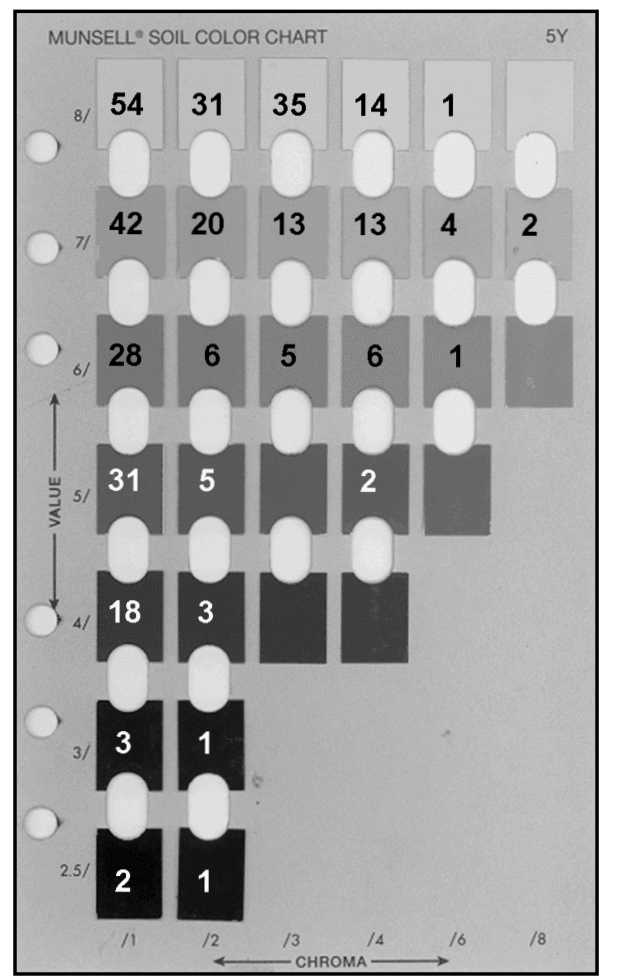

Figura 6. Número de encuestados que eligieron una posición determinada en la escala Munsell (Rock color chart. The Geological Society of America, 1979) como más representativa del color del edificio. Aproximadamente 350 encuenstados en 7 edificios.

Figure 6. Number of respondents choosing a given position on the Munsell colour chart (Rock color chart. The Geological Society of America, 1979) as most representing the building being viewed (about 350 respondents from 7 sites). 
seleccionaron principalmente ventanas de color que reflejaban cambios en oscuridad o luminosidad más que variaciones significativas en croma o tonalidad (Figura 6). En la figura se observa cómo casi la mitad de los encuestados eligieron ventanas de color Munsell con cromas bajos, lo que refleja otra vez los colores tenues característicos de las piedras de edificación. Esto significa que es más probable que un visitante diga que un edificio es demasiado oscuro (o de vez en cuando demasiado claro si ha sido limpiado recientemente), en lugar de decir que es demasiado amarillo o demasiado rojo.

Esto puede cambiar en el futuro, con una población acostumbrada a edificios más limpios que en el pasado. Las personas son muy perceptivas a los colores de la naturaleza, donde son comunes variaciones estacionales en los paisajes en términos de tonalidad y croma (32). Del mismo modo se podrán identificar los cada vez más evidentes cambios de tono y croma en los edificios, resultantes de un amarilleamiento por procesos de oxidación o de la nueva coloración biológica.

\section{CAMBiOS A LARGO PLAZO EN LA CATE- DRAL CATÓLICA DE SAN JUAN BAUTISTA}

Los procesos descritos en los apartados anteriores se pueden ilustrar con los cambios en la fachada norte de la catedral de San Juan Bautista de Norwich, Reino Unido (Figura 7). En esta fachada la distribución de color ha variado constantemente desde su consagración a principios del siglo XX. También hemos intentado estudiar como podría evolucionar a lo largo del siglo XXI. La construcción de la catedral se inició el 24 de junio de 1882 y fue abierta el 8 de diciembre de 1910 (33). El edificio, de aspecto gótico, está rodeado por dos lados por carreteras principales. Las piedras más abundantes son las calizas conocidas como Beer, Ancaster y Clipsham stones (33 y comunicación personal). Beer stone es una caliza de grano fino, de color crema claro y fue utilizada principalmente como sillería. La porosidad es de alrededor del $30 \%$ (34). Esta piedra se ha deteriorado bastante por lo que en las pasadas cinco décadas las reparaciones se han llevado a cabo principalmente con Clipsham stone. Las piedras de Ancaster y Clipsham son más durables y fueron utilizadas en las molduras, vuelos, vierteaguas, albardillas, etc. Estas piedras son calizas de grano medio, de color crema, con porosidades entre $10-20 \%$ (34). La fachada presenta colores grisáceos-blanquecinos de alteración en las áreas construidas con Beer stone y pardoamarillentos en zonas de Clipsham stone.

La evolución de la distribución del color ha sido estudiada mediante:

1) Fotografías históricas. Hemos recopilado más de una docena de fotografías y postales de la catedral desde ma (Figure 6) or hue. Here we see that almost half the respondents choose Munsell colour tablets with the lowest chroma reflecting again the subtle colours typical of natural building stones. This means a visitor is more likely to says that a building is too dark (or occasionally too light for recently cleaned buildings), rather than to say it is too yellow or too red.

In future with a longer public experience of cleaner buildings this may change. Shifts in colour, from oxidative yellowing or new biological colouration, may be more apparent to the visitor. People are sensitised to colours in the natural world, where seasonal shifts in terms of hue and chroma are familiar in landscapes (32), so they may well identify these on buildings.

\section{LONG TERM CHANGES AT THE CATHOLIC CATHEDRAL OF ST. JOHN THE BAPTIST}

The processes described in the sections above can be illustrated with changes on the north façade of the Cathedral Church of St John the Baptist, Norwich UK (Figure 7). Here there has been a development of colour patterns since its consecration at the beginning of the 20th century. We have also tried to consider how these might evolve through to the end of the 21st century. The construction began on 24 June 1882 and the Cathedral Church opened on 8 December 1910 (33). The Gothic style building is surrounded on two sides by major roads. The most predominant stones are Beer, Ancaster and Clipsham limestone (33 and personal communication). Beer is a soft fine-grained, creamy limestone and was typically used for the ashlar work. The porosity is around $30 \%$ (34). This stone has not weathered well and over the last five decades repairs have mostly been undertaken with Clipsham stone. More durable Ancaster and Clipsham were used for moulding, projections, weatherings, copings etc. These stones are medium-grained, buff-creamy limestones with porosities in the range 10$20 \%$ (34). The façade exhibits weathered greyish-whitish colours in areas built of Beer stone and brownish-yellowish in areas of Clipsham stone.

We studied the development of the colouring patterns through:

1) Historic photographs. We have collected more than a dozen photographs and post-cards of the cathedral from 
principio del siglo XX hasta el año 2007. Las más antiguas son, por supuesto, fotografías en blanco y negro, pero así y todo nos han permitido estimar la distribución o los patrones de ennegrecimiento de la fachada norte (Figura 7). Esta distribución se plasmó sobre un alzado de la fachada (Figura 8). El posible aspecto futuro se estimó teniendo en consideración el lavado por la lluvia, los procesos de oxidación y la actividad biológica en un clima en constante cambio. the beginning of 20th Century to 2007. The earliest are of course monochrome photographs, but still allowed us to estimate blackening patterns of the north façade (Figure 7). These were then drawn onto an architectural elevation (Figure 8). Possible future appearance was suggested by considering removal of deposits by changed rainwater flow, oxidation processes and biological activity under a changing climate.

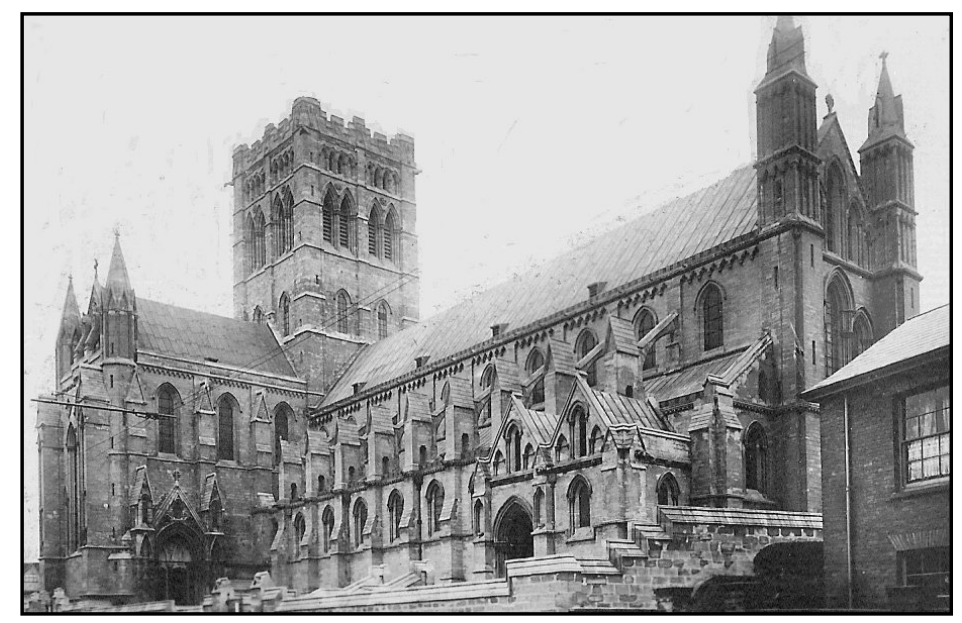

Figura 7. Vista de la fachada norte ( 1915) de la catedral de San Juan Bautista de Norwich, donde se observan la entrada principal y la portada del brazo norte del transepto.

Figure 7. View of the north façade ( 1915) of Norwich cathedral church of St. John the Baptist showing main entrance and north-transept doors.

2) Medidas colorimétricas contemporáneas. Se llevaron a cabo en la fachada ( $<2 \mathrm{~m}$ de alto) en el verano de 2006 con un espectrofotómetro MINOLTA CM-2600d (iluminante D64, haz de luz difusa de $8 \mathrm{~mm}$ de diámetro y un ángulo de observación de $10^{\circ}$ ). Se han realizado 45 medidas en áreas con diferentes tipos de alteración, como por ejemplo, piedra alterada, depósitos negros, áreas amarillentas y costras biológicas. Posteriormente, se llevó a cabo un análisis cluster usando los valores de L*, a* y b* para asignar parámetros de color a los tipos de alteración. Finalmente, se han estimado potenciales cambios en el color global de la fachada norte asumiendo los posibles cambios en las áreas cubiertas por los diferentes tipos de alteración desde 1910 hasta 2100 .

3) Cuestionarios. Los aspectos estéticos se examinaron preguntando a miembros del público, en los años 2002 y 2003, sus opiniones sobre la apariencia del edificio. Las encuestas se realizaron en tres puntos diferentes: a) desde la entrada principal de la iglesia mirando a la portada del brazo norte del transepto, limpiada durante los últimos años (30 encuestados); b) frente a la fachada norte oscura, desde el otro lado de la carretera (30 encuestados); c) muy cerca de la carretera y mirando al
2) Contemporary colorimetric measurements. These were made at the façade $(<2 m$ high) with a Spectrophotometer MINOLTA CM-2600d (illuminant D64, beam of diffuse light of $8-\mathrm{mm}$ diameter, $10^{\circ}$ observer angle) in summer 2006. We took 45 measurements from areas showing different weathering types (e.g. weathered stone, black deposits, yellowed areas and biological crusts). We undertook cluster analysis of the $L^{*}, a^{*}$ and $b^{*}$ values to assign colour parameters to the weathering types. Assuming changes in the areas covered by the different weathering types over the 1910 to 2100 allowed us to estimate the change in the overall colour of the north façade.

3) Questionnaires. Aesthetic considerations were explored by asking members of the public, in 2002 and 2003, their views on the appearance of the cathedral. The questionnaires were carried out, at three points: a) from the main entrance to the church looking at the northtransept doors, which have been cleaned in the last years (30 respondents); b) across a busy to a darker part of the north façade (30 respondents); c) very close to the road and facing the east end of the Cathedral, which appears 
lateral este, que muestra un ennegrecimiento uniforme e intenso. Este trabajo formó parte de un estudio más extenso sobre la percepción de la decoloración de edificios históricos europeos (20). También se solicitó a los encuestados que compararan el aspecto de la fachada con escalas de color. Como se encontró que las personas encuestadas eran más sensibles a cambios en luminosidad que en croma decidimos estimar la luminosidad percibida (Lp).

Las fotografías en blanco y negro de alrededor de 1915 sugieren que la catedral presentaba un aspecto más claro, aunque se pueden distinguir trazas de hollín en algunas zonas, probablemente debidas a la combustión de carbón (Figura 7). El uso de fotografías antiguas nos permitió establecer las distribuciones de color que muestra la Figura 8. Éstas son especulaciones ya que la calidad de las fotografías no es siempre buena y además la zona más fotografiada es el lateral este. Las fotografías de la fachada norte parecen sugerir que se alcanzó un máximo de ennegreciendo alrededor de las décadas de los 60 y 70 . A partir de entonces el edificio parece adquirir unas tonalidades más claras. Esto es probablemente consecuencia del descenso en el uso de carbón, a partir del aumento de las normativas sobre contaminación en el Reino Unido, y del cambio a calefacciones eléctricas y de gas. very and uniformly black. This work formed part of a wider study of the perception of the discoloration of European buildings (20). The respondents were also asked to compare the appearance of the facades with printed scales. As visitors were found to be more sensitive to changes in lightness than chroma we estimated the perceived lightness (i.e. Lp).

Early black and white pictures dated around 1915 suggest that the cathedral had a light appearance, although some traces of soot are seen in a few areas probably due to local coal smoke on parts built earlier (Figure 7). The use of older photographs allowed us to establish early patterns of discoloration as shown in Figure 8. These are necessarily speculative, because the quality of the photographs is not always good and it was the east end that was photographed most frequently. Photographs of the north façade hint that blackening may have reached a peak around 1960s and 1970s and from then the building took on a cleaner appearance. This was probably the result of declining use of coal following the increasing regulation of pollution in the UK and the switch to gas and electric heating (1).

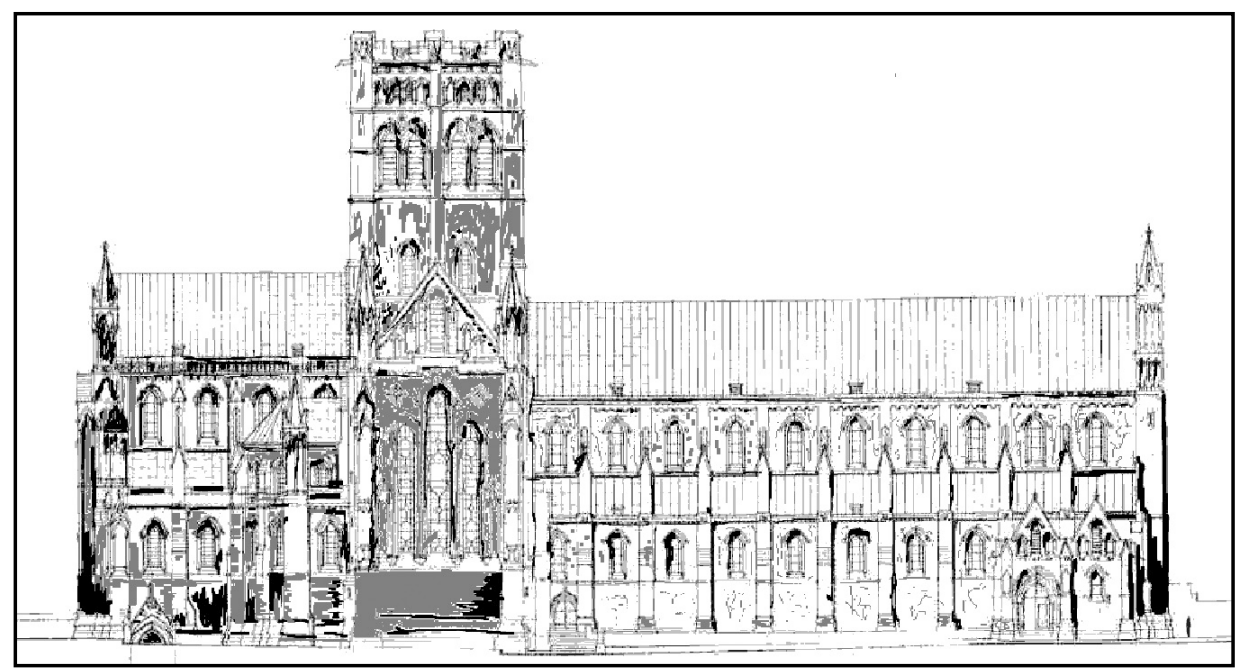

Figura 8. Distribución del ennegrecimiento estimada a partir de fotografías antiguas de la catedral de San Juan Bautista. El color negro indica la superficie ennegrecida alrededor de 1920 y el color gris la superficie adicional cubierta alrededor de 1960.

Figure 8. Patterns of blackening estimated from early photographs of the St. John the Baptist. Black shows area covered by $\sim 1920$ and grey further areas covered by $\sim 1960$.

La lluvia (wind-driven rain) redistribuye los depósitos oscuros ocasionando que las partes superiores de los edificios adquieran tonalidades mucho más claras (5). Las costras negras se conservan principalmente en zonas protegidas bajo los vuelos de piedra. Sin embargo, en el lateral este
Wind driven rain removes or redistributes soot, such that the upper parts of buildings are much lighters (5). Black crusts remain principally under sheltered areas below projections in the stone work. However, on the east end of St. John's Cathedral, close to the road, heavy traffic 
de la catedral de San Juan, situado muy cerca de la carretera, el tráfico intenso hace que se mantenga un aspecto más oscuro, aunque los procesos de oxidación de esta zona parecen estar dando lugar a tonos más cálidos, especialmente en Clipsham stone. Aquí la catedral empieza a mostrar colores más hacia los tonos del marrón y el naranja. Además, el descenso en las concentraciones de dióxido de azufre favorece el crecimiento biológico, especialmente en las partes inferiores. El modelo Hadley HadCM3, usando el escenario de emisiones $A 2$, predice un incremento de temperatura en la parte central de Inglaterra, de alrededor de $3^{\circ} \mathrm{C}\left(\approx 8\right.$ a $\left.11{ }^{\circ} \mathrm{C}\right)$ desde el periodo $1961-90$ hasta el periodo 2070-2099. Un clima más cálido podría favorecer el crecimiento de organismos en la superficie del edificio, aunque en los edificios el papel del agua es dominante. Sin embrago, es posible que en el futuro existan áreas de diferentes coloraciones biológicas.

El probable descenso en la contaminación y la existencia de lluvias más intensas pueden remover parte de los depósitos oscuros, de manera que el edificio se llegue a percibir más claro, pero quizás más amarillento. El color más intenso de las partes sustituidas con Clipsham stone puede ocasionar que la coloración de la fachada se vea a parches. Parte de los depósitos oscuros pueden ser lavados hacia las partes inferiores o permanecer en zonas protegidas de la lluvia, aunque probablemente presenten tonalidades más hacia el marrón. maintains the darker aspect, although here oxidation processes seem to be imposing warmer tones especially on Cliphsam. The cathedral begins to look more brown or orange here. Furthermore, lower concentrations of sulfur dioxide, a phytotoxin, have meant more biological growth, especially lower down. The Hadley HadCM3 Model using the $A 2$ emission scenario predicts a temperature increase of around $3^{\circ} \mathrm{C}\left(\approx 8\right.$ to $11^{\circ} \mathrm{C}$ ) from the periods 1961-90 to 2070-2099 in Central England. A warmer climate could encourage the growth of organisms on building surfaces, although on buildings the water relations are often dominant. Nevertheless there are fears that there will be large areas of different coloured biological growth in future.

Air pollution should decrease and heavier rains from future climate change may remove some soot, so the building is likely to appear lighter, but maybe yellower. The stronger colouration on Clipsham replacements will mean that the colouring could look patchy. Some of the soot will be washed lower down or remain in areas protected from rain, but probably take on more brownish tones.

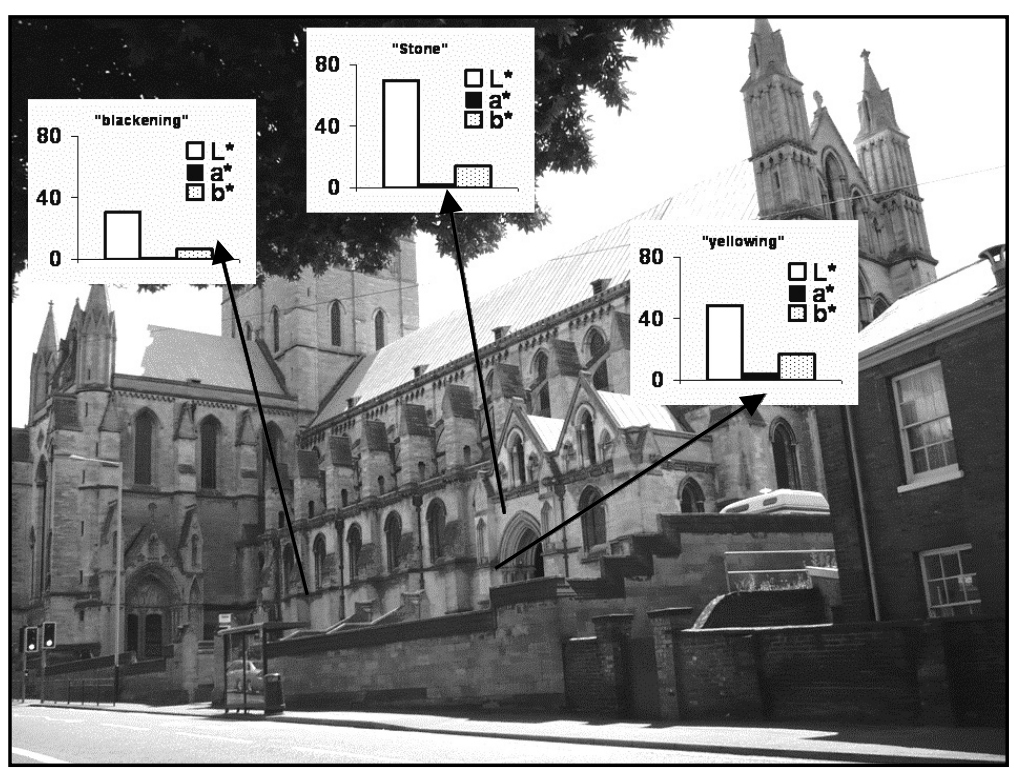

Figura 9. Vista de la fachada norte (2007) de la catedral de San Juan Bautista de Norwich donde se observan la entrada principal y la portada del brazo norte del transepto. Las gráficas muestran los valores medios de los clusters de los parámetros del color de áreas de piedra sin costra, zonas ennegrecidas y zonas amarillentas. Los errores típicos parecen indicar que las diferencias en b* son significativas aunque pequeñas y en el límite de percepción visual. Actualmente solamente son detectadas por expertos en áreas donde el cambio es intenso. Sin embargo, estas diferencias probablemente aumentarán en el futuro.

Figure 9. View of the north façade (2007) of Norwich cathedral church of St. John the Baptist showing main entrance and north-transept doors. Insets show average values of the clusters of the measured colour parameters for crust-free stone, blackened and yellowed areas. The standard error seems to indicate that differences in $b^{*}$ are significant, even if they are subtle and near the limit of human perception, so noticed only by experts in areas of large change. However, the differences will likely increase in the near future. 
A pesar de las limitaciones de la metodología expuesta, la noción de un cambio en el aspecto del edificio puede ser de utilidad a la hora de interpretar las opciones de mantenimiento o de gerencia. A partir de este trabajo, hemos generado un cuaderno de colorear (35) que muestra el aspecto pasado, presente y futuro de la catedral y ofrece interpretaciones de los cambios.

Las medidas actuales de color en zonas específicas del edificio se muestran en la Figura 9. El análisis cluster usando $L^{*}, a^{*}$ y b* ha permitido dividir las medidas en tres grupos principales que representan piedra sin costra, piedra con amarilleamiento y costras y áreas de ennegrecimiento.

Hemos usado los valores medios de L*, a* y b* de cada uno de los tres tipos de envejecimiento para estimar, según el área cubierta por cada tipo, el tono de la fachada norte a lo largo del tiempo (Figura 10). Las áreas se estimaron visualmente a partir de las distribuciones de color de las fotografías históricas dibujadas sobre el alzado de la fachada. Aunque el método es bastante básico, coincide razonablemente con la percepción del público sobre la reflectancia global de la fachada $\left(L_{p}\right)$ que se estableció a partir de los cuestionarios. Los responsables de la gerencia del edificio, están como es natural, interesados en los posibles colores futuros del edificio, de modo que van a tener que considerar la posibilidad que exista una parte pequeña del edificio con costra negra y un aumento en los tonos cálidos de Clipsham stone. Una idea de los cambios que se están produciendo nos fue dada por personas con un especial interés en la catedral
Despite the limitations of this approach the notion of a changing appearance has useful in interpreting management options to the public. One product of our work was a paint-by-numbers colouring book which showed the Cathedral Church, past, present and future and offered interpretations of the changes (35).

Contemporary colour measurements from specific locations are shown in Figure 9. Cluster analysis of $L^{*}, a^{*}$ and $b^{*}$ divides the measurements neatly into three main groups that represent the crust-free stone, yellowing aged stone and crusts and areas of blackening.

We used the average values of $L^{*}$ and $b^{*}$ for each of these three surface types to estimate the area weighted colour tone of the north façade through time (Figure 10). These areas were estimated visually from the colour patterns from historic photographs drawn onto architectural elevations. Although this method is necessarily crude there is a reasonable agreement with the visitor perceptions overall reflectance $\left(L_{p}\right)$ as established by the questionnaire. Managers are naturally interested in the future colours that the building may take on, so they have to consider that there may be a small area of remaining black crust and an increasing warm tone to the Clipsham. A sense of the changes underway was given by visitors with a special interest in the cathedral during walking tours close to the stone work in the summer of 2006.

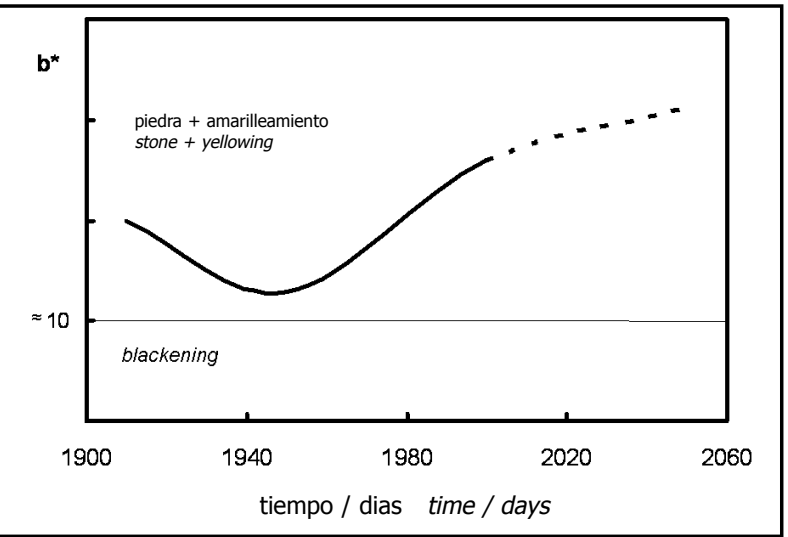

Figura 10b / Fugure 10b

Figura 10a. Luminosidad $\left(L^{*}\right)$ estimada, según la distribución de colores, para la fachada norte de San Juan Bautista en función del tiempo. El punto $L_{p}$ representa la luminosidad percibida por las personas encuestadas en 2002.

Figure 10b. Valor global de la coordenada cromática b* estimada para la fachada norte en function del tiempo. Los nombres de los grupos (piedra, amarilleamiento, ennegrecimiento) colocados en el eje $\mathrm{Y}$ indican los valores de las áreas representadas en los histogramas de la Figura 9.

Figure 10a. The area weighted lightness $\left(L^{*}\right)$ estimated for the north façade of St. John the Baptist as a function of time. The point $L_{p}$ shows the lightness perceived by visitors in 2002.

Figure 10b. The area weighted colour coordinate $b^{*}$ estimated for the north façade as a function of time. The clusters noted by position on the Y-axis ("stone", "yellowing", "blackening") denote the values of areas marked within histograms in Figure 9. 
durante las visitas guiadas en el verano del 2006. Estas quedaron impresionadas por los tonos cálidos de algunas partes de la fachada.

\section{CONCLUSIONES}

Como es bien conocido, el color de los edificios cambia a lo largo del tiempo debido al depósito de contaminantes. Si estos cambios de color coinciden con la ideas arquitectónicas de envejecimiento, la superficie alterada se puede considera una pátina. No obstante, en el pasado era común la formación de gruesas costras negras como consecuencia de la combustión de carbón, que originaba un cambio en el aspecto edificio en muy pocos años. En el presente se han mejorado mucho los niveles de contaminación atmosférica, que además es muy diferente, siendo los automóviles su fuente principal. Todavía existe la posibilidad de ennegrecimiento, aunque las capas depositadas son probablemente de diferente composición.

Los edificios cuando se oscurecen tienden a alcanzar un valor límite de reflectancia que depende de la carga de carbono elemental. Los depósitos actuales tienden a ser más finos y menos oscuros. Actualmente, los depósitos negros antiguos están siendo lavados por la acción de la lluvia. Sin embargo, el balance entre depósito y redistribución no está bien cuantificado y representa un área importante de investigación en el futuro.

El clima futuro puede afectar el aspecto de los edificios por el cambio en la cantidad y la dirección de la lluvia. Las superficies cada vez más limpias de las fachadas facilitan la percepción del color del edificio. Sin embargo, los nuevos depósitos son más ricos en compuestos orgánicos derivados del petróleo y su oxidación resulta en tonos más cálidos de las superficies de piedras de colores claros. Climas más cálidos favorecen la aparición de nuevos ecosistemas en las superficies de las piedras y un cambio adicional en el aspecto del edificio.

La población, acostumbrada a los edificios sucios del pasado, ha tenido recientemente que confrontar grandes cambios. Los edificios comenzaron a tener un aspecto más limpio, bien gracias a obras de restauración o por la acción de la lluvia en ambientes urbanos menos contaminados. Estos cambios rápidos dan lugar a un aspecto no familiar de los edificios, lo que puede no ser del gusto de todos. Actualmente ya hay algunas personas que empiezan a notar el cambio sutil hacia tonalidades más amarillentas o marrones en estos edificios más limpios. Estas alteraciones en las tonalidades de los edificios de piedra es probable que continúen en futuros ambientes urbanos. Los métodos de gerencia del pasado, donde se consideraban ciclos de mantenimiento a intervalos más o menos fijos de tiempo, pueden dejar de ser efectivos. Los
They were struck by the warm tones on some parts of the façade.

\section{CONCLUSIONS}

It is well known that the colour of buildings changes over time as pollutants are deposited. If these colour changes fall within the architect's concepts of the ageing process the altered surface can reasonably be called a patina. However, in the past heavy black crusts formed on the surfaces from the deposition of coal smoke. This changed the appearance of buildings over just a few years. Urban pollution is now much improved, but very different with automotive sources predominant. There is a potential for blackening although the crust is likely to be of different composition.

As buildings darken they approach a limiting value for reflectance that is dependent on the elemental carbon load. Modern deposits are likely to be thinner and less dark. Older black deposits are now remove from façades by rain washing. However, the balance between deposition and redistribution is not well quantified and represents an important area of future research.

Future climate can affect the appearance of buildings by altering rainfall amount and direction. The evolving cleaner surfaces allow the underlying building colour to be more apparent. However, the newer deposits appear richer in organic compounds derived from petroleum, so their oxidation results in warmer tones to many light coloured building stones. Warmer climates promote novel ecosystems on stone surfaces and further changing the appearance of the building.

The public, accustomed to grimy buildings of the past has recently had to confront dramatic changes. Buildings were cleaned as part of restoration works or washed by rain in less polluted urban environments. Such rapid changes create an unfamiliarity that was not always welcome. We now have cleaner buildings and some more observant members of the public are beginning to notice rather subtle shifts to yellow or brownish tones. The alteration in the tone of stone buildings is likely to continue under future urban climates. Simple management approaches of the past that cycles of maintenance at fixed intervals may no longer be effective. Recleaning periods may have to vary, and the approach account for different 
periodos de limpieza van a tener que variar y considerar los diferentes tipos de contaminantes. También será necesario tener en cuenta las nuevas percepciones de los edificios que van a mostrar colores más tenues.

\section{AGRADECIMIENTOS}

Este trabajo ha sido financiado por los proyectos europeos CARAMEL (ENV4-CT-2000-0002) y NOAH'S ARK (CT-2003501837) y por los proyectos españoles CICYT (CC95SEC0501 y 1FD97-0331-C03-01) y FICYT (PB-REC96-98). También queremos dar las gracias a la Profesora R.M. Esbert (Universidad de Oviedo, España), a la Profesora C. Sabbioni y a la Doctora A. Bonazza (CNR, Italia) por permitirnos usar los datos de los mencionados proyectos, así como a Dña. Naomi Perowne, D. Anthony Rossi y el personal de la catedral católica de San Juan Bautista de Norwich por facilitarnos el acceso a la iglesia. types of deposit. Management will also need to confront novel perceptions as more subtle colorations are revealed.

\section{ACKNOWLEDGEMENTS}

This paper has benefited from EU funding within the projects CARAMEL (ENV4-CT-2000-0002) and NOAH'S ARK (CT-2003-501837) and Spanish funding from CICYT (CC95-SEC0501 and 1FD97-0331-C03-01) and FICYT (PBREC96-98). We also are very grateful to Prof R.M. Esbert (Universidad de Oviedo, Spain) and Prof C. Sabbioni and $\operatorname{Dr}$ A. Bonazza for allowing us to use data from the above projects. We would also like to thanks Ms Naomi Perowne, Mr Anthony Rossi and the personal of The Roman Catholic Cathedral of St. John the Baptist in Norwich (UK) for allow us the access to the church.

\section{BIBLIOGRAFÍA / BIBLIOGRAPHY}

(1) Brimblecombe, P.: "The Big Smoke". Methuen, London. (1987).

(2) Newby, P. T,. Mansfield, T. A., Hamilton, R.S.: "Sources and economic implications of building soiling in urban areas". Science of the Total Environment, 100 (1991), pp. 347-65.

(3) Matteini, M.: "Le patine. Genesi, significato, conservazione". Workshop organized by M. Matteini. Nardini (ed.) Istituto per la Conservazione e Valorizzazione dei Beni Culturali del CNR, (2005).

(4) Lanting, R. W.: "Black smoke and soiling". In: Lee, S. D., Schneider, T., Grant, L. D. \& Verkerk, P. J. (eds) Aerosols. Lewis Publishers, Boca Raton, FL (1986), pp. 923-932.

(5) Davidson, C., Tang, W., Finger, S., Etyemezian, V., Striegel, F., Sherwood, S.: "Soiling patterns on a tall limestone building: Changes over 60 years". Environmental Science and Technology, 34 (2000), pp. 560-565.

(6) Viles, H. A., Gorbushina, A. A.: "Soiling and microbial colonisation on urban roadside limestone: a three year study in Oxford, England". Building and Environment, 38 (2003), pp. 1217-1224.

(7) Thornbush, M., Viles, H. A.: "Integrated digital photography and image processing for the quantification of colouration on soiled limestone surfaces in Oxford, England". Journal of Cultural Heritage, 5 (3) (2004), pp. 285-290.

(8) Thornbush, M., Viles, H. A.: "Changing patterns of soiling and microbial growth on building stone in Oxford, England after implementation of a major traffic scheme". Science of the Total Environment, 367 (1) (2006), pp. 203-211.

(9)Bonazza, A., Sabbioni, C., Ghedini, N., Hermosin, B., Jurado, V., M.Gonzalez, J., Saiz-Jimenez, C.:" Did smoke from the Kuwait oil well fires affect Iranian archaeological heritage?". Environmental Science and Technology, 41 (7) (2007), pp. 2378-2386.

(10) Garcia-Vallés, M., Vendrell-Saz, M., Molera, J., Blazquez, F.: "Interaction of rock and atmosphere: Patinas on Mediterranean monuments". Environmental Geology, 36 (1-2) (1998), pp. 137-149.

(11) S.Valls Del Barrio, M. Garcia-Valle's, T. Pradell, M.Vendrell-Saz: "The red-orange patina developed on a monumental dolostone. Engineering Geology, 63 (1-2) (2002), pp. 31-38.

(12) Vázquez-Calvo, C., Álvarez de Buergo, M., Fort, R.: "Overview of recent knowledge of patinas on stone monuments: the Spanish experience". Geological Society Special Publication, 271 (2007), pp. 295-307.

(13) Grossi,C. M., Brimblecombe, P., Esbert, R. M. Alonso, F. J.: "Color changes in architectural limestones from pollution and cleaning". Color Research and Application, 32 (4) (2007), pp. 320-331.

(14) Fort, R., López de Azcona, M. C., Mingarro, F.: "Cleaning of stone materials in the Cathedral de Valladolid (Spain)". Mater. Construcc., 50 (2000), pp. 37-50.

(15) Gaviño, M., Hermosín, B., Castillejo, M., Ojuda, M., Rebollar, E., Vergès-Belmin, V., Nowick, W., Saiz-Jiménez, C.: "Black crusts removal: the effect of stone yellowing and cleaning strategies". In: Saiz-Jiménez C, editor. Air Pollution and Cultural Heritage. London: AA Balkema (2004). pp 239-245.

(16) Potgieter-Vermaak, S. S., Godoi, R.H.M., Van Grieken, R., Potgieter, J. H., Oujja, M., Castillejo, M.: "Micro-structural characterization of black crust and laser cleaning of building stones by micro-Raman and SEM techniques". Spectrochimica Acta Part A-Molecular and Biomolecular Spectroscopy 61 (11-12) (2005), pp. 2460-2467.

(17) Andrew.C.: "Towards an aesthetic theory of building soiling": In: WEBSTER, R. G. M. (ed.) Stone Cleaning and the Nature, Soiling and Decay Mechanisms of Stone. Donhead, London (1992), 63-81.

(18) Brimblecombe, P., Grossi: C.M.: "Aesthetic thresholds and blackening of stone buildings". Science of the Total Environment, 349 (2005), pp. 175-189. 
(19) Grossi, C. M., Brimblecombe, P.: "Aesthetics of simulated soiling patterns on architecture". Environmental Science \& Technology, 38 (2004), pp. 3971-3976.

(20) Grossi, C. M., Brimblecombe, P.: "Aesthetics and perception of soiling". In: Saiz-Jimenez, C. (ed.) Air Pollution and Cultural Heritage. A. A. Balkema, Rotterdam (2004), pp. 199-208.

(21) Grossi, C.M., Brimblecombe, P.: "Effect of long-term changes in air pollution and climate on the decay and blackening of European stone buildings". Geological Society Special Publication, 271 (2007), pp. 117-130.

(22) Brimblecombe, P., Grossi, C. M.: "The rate of darkening of material surfaces". In: Saiz-Jimenez, C. (ed.) Air Pollution and Cultural Heritage. A. A. Balkema, Rotterdam (2004), 193-198.

(23) Watt, J.: "Quantifying the Effects of Air Pollution on the Soiling of Materials". Abstracts of the CULT-STRAT Workshop: The Protection of Cultural heritage from Air Pollution", Paris (2007).

(24) Grossi, C. M., Esbert, R. M., Díaz-Pache, F.: Alonso, F. J.: "Soiling of building stones in urban environments". Building and Environment 38 (2003), pp. $147-159$

(25) Lombardo, T., Ionescu, A., Lefèvre, R.A., Chabas, A., Ausset, P., Cachier, H.: "Soiling of silica-soda-lime float glass in urban environment: Measurements and modelling": Atmospheric Environment, 39 (6) (2005), pp. 989-997.

(26) Ionescu, A., Lefèvre, R. A., Chabas, A., Lombardo, T., Ausset, P., Candau, Y., Rosseman, L.: "Modeling of soiling based on silica-sodalime glass exposure at six European sites". Science of the Total Environment, 369 (1-3) (2006), pp. 246-255.

(27) Esbert, R. M., Grossi, C. M., Alonso, F. J., Ordaz, J., Díaz-Pache, F.: Projects CICYT: CC95-SEC0501 and FICYT: PB-REC96-98, Internals Reports. Universidad de Oviedo (1997).

(28) Bonazza, A., Brimblecombe, P., Grossi, C.M., Sabbioni, C.: "Carbon in Black Crusts from the Tower of London". Environmental Science and Technology, 41 (12) (2007), pp. 4199-4204.

(29) Sillanpaa, M., Frey, A., Hillamo, R., Pennanen, A. S., Salonen, R. O.: "Organic, elemental and inorganic carbon in particulate matter of six urban environments in Europe". Atmospheric Chemistry and Physics 5 (2005), pp: 2869-2879.

(30) Bonazza, A., Sabbioni, C., Ghedini, N.: "Quantitative data on carbon fractions in interpretation of black crusts and soiling on European built heritage". Atmospheric Environment, 39 (14) (2005), pp. 2607-2618.

(31) Graber, E. R., Rudich, Y.: "Atmospheric HULIS: How humic-like are they? A comprehensive and critical review". Atmospheric Chemistry and Physics, 6(3) (2006), pp. 729-753.

(32) Hering, B.: "Seasonal changes of dominating hues in Landscapes close to nature". Spoken Version, ICC], Budapest (2007).

(33) Rossi, A.: "Norwich Roman Catholic Cathedral. A Building History". Miscellany 1, The Chapels Society. Oblong Creative Ltd, Wetherbery (1998).

(34) The BRE / British Stone Stone List: http://projects.bre.co.uk/condiv/stonelist/beer.html.

(35) Green, A., Brimblecombe, P., Grossi, C. M., Judge, P.: "The Colour of Time". (2006). Published by the Cathedral Church of St. John the Baptist, Norwich. 